\title{
Robot Technology Workbook
}




\section{City and Guilds Co-publishing Series}

City and Guilds of London Institute has a long history of providing assessments and certification to those who have undertaken education and training in a wide variety of technical subjects or occupational areas. Its business is essentially to provide an assurance that pre-determined standards have been met. That activity has grown in importance over the past few years as government and national bodies strive to create the right conditions for the steady growth of a skilled and flexible workforce.

Both teachers and learners need materials to support them as they work towards the attainment of qualifications, and City and Guilds is pleased to be working with several distinguished publishers towards meeting that need. It has been closely involved in planning, author selection and text appraisal, although the opinions expressed in the publications are those of the individual authors and are not necessarily those of the Institute.

City and Guilds is fully committed to the projects listed below and is pleased to commend them to teaching staff, students and their advisers.

Carolyn Andrew and others, Business Administration Level I and Business Administration Level II, John Murray

David Minton, Teaching Skills in Further and Adult Education, Macmillan

Graham Morris and Lesley Reveler, Retail Certificate Workbook (Levels 1 and 2), Macmillan

Peter Riley (consultant editor), Computer-aided Engineering, Macmillan

Barbara Wilson, Information Technology: the Basics, Macmillan

Caroline Wilkinson, Information Technology in the Office, Macmillan 


\section{Robot Technology Workbook}

\section{David Cumbers}

Department of Engineering

Ebbw Vale College of Further Education

Consultant Editor: Peter Riley

Head of Department of Engineering Technology Blackpool and The Fylde College 
All rights reserved. No reproduction, copy or transmission of this publication may be made without written permission.

No paragraph of this publication may be reproduced, copied or transmitted save with written permission or in accordance with the provisions of the Copyright, Designs and Patents Act 1988, or under the terms of any licence permitting limited copying issued by the Copyright Licensing Agency, 90 Tottenham Court Road, London W1P 9HE.

Any person who does any unauthorised act in relation to this publication may be liable to criminal prosecution and civil claims for damages.

First published 1993 by

THE MACMILLAN PRESS LTD

Houndmills, Basingstoke, Hampshire RG21 2XS

and London

Companies and representatives

throughout the world

ISBN 978-0-333-56508-7

DOI 10.1007/978-1-349-12688-0

A catalogue record for this book is available from the British Library.

\section{Acknowledgements}

The author and publishers would like to thank the following for their help in providing illustrations: M. T. Churcher (Figs 7.1, 15.1 and 15.2), ASEA Brown Boveri (Fig. 9.1) and Stäubli Unimation (Fig. 14.1). 


\section{Contents}

Introduction vi

How to use this book 1

1 Robot arm and wrist movements 2

2 The end-effector 4

3 Drive actuators Part I 6

4 Drive actuators Part II 8

5 Mechanical transmissions 10

6 The workcell and safety 12

7 Robot control systems Part I 14

8 Robot control systems Part II 16

9 Programming a robot 18

10 Program editing 20

11 External sensing: tactile sensors 22

12 External sensing: vision sensors 24

13 Robot performance 26

14 Process applications of robots 28

15 Robot arm maintenance 30

16 System maintenance 32

Index 34 


\section{Introduction}

Programmable handling systems and robot technology are essential elements in many industrial processes. The assignments in this workbook will provide a broad range of practical experiences which represent a valuable foundation to the successful application of this technology.

The subject is a diverse one, involving many traditionally separate engineering disciplines. Because of this, practical activities have been carefully selected to create a comprehensive yet cohesive programme of study which closely follows the City and Guilds 230 computer-aided engineering series robot technology syllabus. This workbook will also prove to be a useful aid to those studying standard modules in robot technology available through the Business and Technology Education Council (BTEC).

The approach in all the assignments concerns the practical application of robot technology. This ranges from machine selection to workcell maintenance. Programming is also included, together with the many uses of feedback information and sensing systems. This is a multi-disciplined technology which demands a multi-skilled engineer for effective application. The workbook will be particularly suitable for:

- recently trained engineers wishing to advance to more specialised new technology work

- mature, skilled and experienced engineers who require to update and enhance their traditional skills with robot technology disciplines

- service and maintenance personnel who require to broaden their skills and knowledge base in response to multi- and inter-disciplinary developments in the field of robot technology

- technical trainers and teachers who are seeking to acquire new technology skills in response to changing course demands.

The result of rapid technological advances in industry is that there has never been a more exciting time to be an engineer. This workbook has been written for those concerned with sharing and exploiting the benefits that may be derived from this new technology and its associated working methods.

\section{City and Guilds/Macmillan publishing for computer-aided engineering}

This workbook is one of a series of City and Guilds/Macmillan books which together give complete and up-to-date coverage of computer-aided engineering. The books complement each other but can be used independently of each other.

A core text, or source book (Computer-aided Engineering), gives basic information on all the main topic areas (basic CNC; CNC setting and operation; CNC part programming; CNC advanced part programming; basic CAD/CAM; computer-aided draughting; advanced CAD; basic robotics; robot technology; basic programmable logic controllers; more advanced programmable logic controllers). Tasks are structured into the text to encourage active learning.

Additional workbooks cover five main topics: $\mathrm{CNC}$ setting and operation; CNC part programming; computer-aided draughting; robot technology; programmable logic controllers. Each includes all the operational information and guidance needed to be able to complete the practical assignments and projects.

Peter Riley (Head of Department of Engineering Technology, Blackpool and The Fylde College) is Consultant Editor of the series. 